\title{
Profil Tunarungu Penyandang Gelar Uni Duta Wisata Kota Padang Panjang Tahun 2018
}

\author{
Nurul Nafisah \& Asep Ahmad Sopandi \\ Universitas Negeri Padang, Indonesia \\ Email :19nurul@gmail.com
}

\begin{abstract}
Abstrak
Penelitian ini didasarkan pada hasil temuan lapangan berupa hadirnya seorang penyandang tunarungu pada ajang pemilihan uda uni duta wisata kota padang panjang yang dilaksanakan tahun 2018. Ia yang menjadi salah satu duta wisata terpilih dengan gelar penghargaan special achievment. berdasarkan temuan di lapangan, diperoleh fakta bahwasanya subjek merupakan penyandang disabilitas pertama se kota padang panjang, dan bahkan yang pertama se provinsi sumatera barat. Tujuan dari penelitian ini adalah untuk mengetaahui seluk beluk perjalanan subjek dalam meraih gelar tersebut pada ajang pemilihan uda uni duta wisata kota padang panjang tahun 2018. Adapun penelitian ini menggunakan metode deskriptif kualitatif guna mengungkap secara mendalam profil dari duta wisata penyandang tunarungu. sedangkan metode pengumpulan data yang digunakan pada penelitian ini yaitu melalui observasi terusterang, observasi tersamar, dan observasi tidak terstruktur, study dokumentasi, dan wawancara dengan rekan-rekan terdekat subjek, rekan-rekan sesama duta wisata, juga pihak dinas terkait. Hasil penelitian ini bertujuan untuk mengungkapkan profil dari seorang tunarungu yang menyandang gelar sebagai duta wisata yaitu riwayat pendidikan, aspek 3B (brain, beauty, behavior) yang ada dalam diri tunarungu I, tahapan yang ia lalui dan kendala yang ia hadapi selama berkompetisi dalam ajang pemilihan Uda Uni Duta Wisata Kota Padang Panjang Tahun 2018 dan cara tunarungu I mengatasi kendala yang ia temui dalam kompetisi tersebut.
\end{abstract}

Kata kunci : Tunarungu, Duta Wisata, Uda Uni, Kota Padang Panjang, Profil

\section{Pendahuluan}

Pada hakikatnya, manusia itu diciptakan oleh Tuhan dengan kekurangan dan kelebihannya masing-masing. Manusia terlahir ke dunia dalam berbagai kondisi, ada yang terlahir dengan sempurna tanpa kekurangan satu apapun, ada pula yang terlahir dengan berkebutuhan khusus. Kebutuhan khusus sendiri ada bermacam-macam. Namun tidak sedikit dari mereka yang justru memiliki potensi yang jauh lebih baik dibandingkan dengan mereka yang tidak memiliki kekurangan satu apapun. Bahkan dengan kekurangan yang mereka miliki, mereka justru jauh lebih unggul dalam prestasi dibanding dengan kebanyakan orang. Kesempatan selalu terbuka luas bagi siapapun yang ingin mencoba untuk berkompetisi tanpa terkecuali dengan anak berkebutuhan khusus. 
Salah satu dari kebutuhan khusus tersebut adalah tunarungu.Tunarungu adalah seseorang yang mengalami gangguan pendengaran yang meliputi seluruh gradasi ringan, sedang, dan sangat berat yang dalam hal ini dapat dikelompokan menjadi dua golongan, yaitu kurang dengar dan tuli, yang menyebabkan terganggunya proses perolehan informasi atau bahasa sebagai alat komunikasi. Dalam hal perkembangan, anak tunarungu mengalami perkembangan sama seperti anak pada umumnya kecuali dari segi komunikasi verbal. Mereka juga akan tumbuh menjadi remaja dengan tugas perkembangan yang juga sama dengan anak normal yaitu melakukan penyesuaian diri dan sosial. Namun,dikarenakan hambatannya tersebut, tugas perkembangan untuk menyesuaikan diri dengan lingkungan dan sosial tersebut menjadi lebih berat pada remaja tunarungu. Karena proses interaksi sosial menuntut adanya komunikasi yang tentu saja tidak dapat dihindari oleh remaja tunarungu.

Pada kasus ini, penulis telah berjumpa dengan seorang remaja perempuan berusia 17 tahun penyandang tunarungu dengan inisial "I" yang sangat berprestasi. Awal perjumpaan terjadi saat penulis sedang melaksanakan Praktik Lapangan Kependidikan (PLK) di SLB YPAC SUMBAR tahun 2019. Ia pada saat itu sedang berkunjung kembali ke YPAC dalam rangka libur beberapa hari saat kelas XII sedang melaksanakan ujian pada tanggal 2 April 2019. Dari pembicaraan singkat dengan beliau, penulis mengetahui bahwasanya dulu beliau merupakan salah satu murid pada SLB tersebut, namun beliau memilih untuk pindah mengikuti orangtuanya ke Kota Padang Panjang pada tahun 2009 setelah kejadian gempa bumi hebat melanda provinsi SUMBAR dan sekitarnya Dari sanalah komunikasi via chat sering terjadi, dan belakangan penulis mengetahui bahwa I merupakan salah satu pemenang terpilih pada ajang pemilihan Uda Uni Duta Wisata Kota Padang Panjang Tahun 2018. Ia berhasil membuktikan diri bahwa dengan keterbatasannya mampu mengalahkan para pesaingnya yang merupakan remaja normal.

Penyelenggaraan pemilihan duta wisata adalah bagian integral dari pembangunan dunia pariwisata juga pelestarian unsur seni dan budaya nasional seiring waktu berjalan kriteria penilaian duta wisata akan selalu ditingkatkan sesuai dengan perkembangan zaman guna menigkatkan kualitas dari mereka yang terpilih kelak dengan menitikberatkan pada penilaian menyeluruh terhadap perpaduan seluruh komponen, hal itu terkait perpaduan terbaik atas aspek mencakup pengetahuan umum pemerintah pusat dan daerah; pengetahuan sejarah dan kebudayaan daerah; pariwisata dan public speaking etika dalam berbusana dan penguasaan bahasa; psikologi dan pengembangan diri

Hal ini merupakan sejarah bagi banyak pihak karena ini merupakan yang pertama sepanjang sejarah pemilihan Uda Uni Duta Wisata Kota Padang Panjang bahkan dalam ajang pemilihan duta wisata provinsi SUMBAR, seorang remaja tunarungu dinobatkan sebagai salah satu pemenang ajang tersebut Sementara kita mafhum bahwasanya ajang pemilihan duta wisata merupakan suatu ajang untuk menunjuk putra dan putri terbaik perwakilan dari daerahnya untuk bekerjasama dengan pihak Dinas Pariwisata dalam mempromosikan semua potensi wisata yang dimiliki oleh daerah tersebut melalui sosial 
media, brosur, spanduk, dan sebagainya, tidak lupa pula dengan sosialisasi langsung kepada para wisatawan..

Dalam pelaksanaan pemilihan duta wisata, ada beberapa kriteria yang dijadikan parameter penilian. Kriteria tersebut tidak hanya dari segi keindahan ragawi (beauty), namun juga mempertimbangkan aspek kecerdasan intelektual (brain), serta aspek kecerdasan emosional yang diwujudkan dalam sikap dan tindakan (behavior) secara presisi dan proporsional. Ketiga aspek tersebut yang merupakan modal para duta wisata demi meningkatkan kemajuan dari sektor pariwisata nasional yang berlandaskan prinsip Sapta Pesona. Prinsip tersebut merupakan sebuah kondisi yang ditargetkan untuk meningkatkan kunjungan wisatawan. Prinsip sapta pesona yaitu: aman, bersih, tertib, indah, sejuk, ramah tamah, serta kenangan (PUTRA, 2017)

Untuk menjadi seorang duta wisata kita haruslah melalui proses seleksi yang ketat serta banyaknya kriteria. Kriteria pemilihan duta wisata tidak hanya mengenai aspek keindahan ragawi (beauty), juga mempertimbangkan aspek kecerdasan intelektual (brain) dan kecerdasan emosional yang bermuara pada perilaku (behavior) secara proporsional. Aspek-aspek tersebutlah yang nantinya akan menjadi modal seorang duta wisata dalam mempromosikan dan mengembangkan sektor pariwisata nasional Dan seperti yang telah dijabarkan sebelumnya, bahwa tunarungu mengalami hambatan dalam hal komunikasi, tetapi I justru mengubah prespektif semua orang dengan kekurangannya tersebut dengan meraih prestasi yang gemilang dalam bidang yang bertentangan dengan kebutuhan khusus yang dimilikinya. Hal ini tentunya membuka banyak kesempatan untuk remaja berkebutuhan khusus lainnya untuk tidak menyerah dalam menggapai prestasi dan juga sebagai bukti nyata bahwa kebutuhan khusus sama sekali bukan hambatan untuk berprestasi.

Adapun tujuan dari penelitian ini adalah untuk mengetahui lebih dalam profil dari tunarungu I dalam meraih prestasi pada pemilihan Uda Uni Duta Wisata Kota Padang Panjang Tahun 2018, yang meliputi: deskripsi riwayat pendidikan tunarungu I, deskripsi aspek Brain, beauty, behavior yang ada dalam diri tunarungu I, deskripsi rangkaian kegiatan yang dijalani tunarungu I pada ajang Uda Uni Duta Wisata Kota Padang Panjang Tahun 2018. Mengungkap kendala yang dialami tunarungu I dalam rangkaian kegiatan sebagai Uni Duta Wisata Kota Padang Panjang Tahun 2018 serta menjabarkan cara yang digunakan tunarungu I dalam mengatasi kendala yang ia alami sebagai seorang Uni Duta Wisata Kota Padang Panjang Tahun 2018

\section{Metode}

Dalam penelitian ini diggunakan jenis penelitian studi kasus yang termasuk dalam pendekatan kualitatif. Studi kasus adalah suatu penelitian dimana sang peneliti menggali suatu fenomena tertentu (kasus) dalam suatu waktu dan kegiatan seperti even, program, proses, fenomena sosial, dan sebagainya, lalu mengumpulkan data berupa informasi secara rinci serta mendalam menggunakan berbagai metode pengumpulan data dalam waktu tertentu (Kusmarni, 2012) 
Penulis melihat fenomena atau kejadian yang sesungguhnya secara menyeluruh dan mendalam mengenai profil remaja tunarungu I yang menyandang gelar sebagai uni duta wisata dalam acara pemilihan uda uni duta wisata kota Padang Panjang 2018. Serta gambaran yang diperoleh dari hasil pengamatan terhadap segala fenomena-fenomena alami yang terjadi akan dideskripsikan. Perihal mengamati, penulis melaksanakannya dengan alamiah dan terbuka. Penulis memperhatikan kondisi alamiah dari tunarungu I dalam kesehariannya di rumah maupun di sekolah. Lalu, pengamatan terbuka yang penulis lakukan yaitu dengan mengamati secara nyata dengan sepengetahuan tunarungu I sebagai subjek penelitian ini dan sepengetahuan dari responden penelitian, diantaranya keluarga, dan teman-temannya, peneliti juga mengamati tunarungu I secara diam-diam

Adapun studi kasus ini dilaksanakan pada tiga lokasi, yaitu SMAN 3 Padang Panjang yang merupakan tempat tunarungu I bersekolah, rumah dari tunarungu I, dan kantor Dinas Pariwisata Kota Padang Panjang. Menurut (Yusuf Muri, 2007) Penelitian studi kasus lebih terfokus pada satu fenomena saja yang ditentukan serta dipahami secara mendalam, artinya mempelajari, mengkaji dan mengupas secara mendalam segala aspek yang merupakan sebab terjadinya kasus tersebut. Menurut (Yusuf Muri, 2014) Penelitian studi kasus sangat memperhatikan detail aspek-aspek yang penting dalam suatu kasus yang diteliti. Penelitian ini akan mengungkap gambaran secara mendalam dan mendetail tentang suatu kejadian atau suatu kasus yang tengah terjadi. Kasus yang diteliti bisa satu orang, satu keluarga, peristiwa dan kelompok-kelompok lain yang sangat terbatas, sehingga penelitian ini lebih detail dan mendalam.

Dalam penelitian ini, penulis akan melihat fenomena atau kejadian yang sesungguhnya secara menyeluruh dan mendalam mengenai profil remaja tunarungu I yang menyandang gelar sebagai uni duta wisata dalam acara pemilihan uda uni duta wisata kota Padang Panjang 2018. Serta gambaran yang diperoleh dari hasil pengamatan terhadap segala fenomena-fenomena alami yang terjadi akan dideskripsikan

\section{Hasil Penelitian dan Pembahasan}

\section{Hasil}

Subyek penelitian ini adalah seorang siswi tunarungu yang memiliki prestasi dibidang non-akademik yang peneliti beri inisial I, lomba yang pernah diikutinya yaitu pemilihan Uda Uni Duta Wisata Kota Padang Panjang Tahun 2018 dan berhasil meraih penghargaan sebagai Uni Special Achievment. Ini merupakan bentuk penghargaan atas upayanya dalam berkompetisi dengan pesaing yang merupakan orang normal. I merupakan anak ke tiga dari empat bersaudara . Beliau lahir pada tanggal 12 Mei 2001 di Tanah Datar. I merupakan seorang siswi di kelas XII IPS 3 SMAN 3 Padang Panjang.

Selanjutnya, I juga menjadi pemeran utama dalam film dengan judul "Tanpa Batas" yang mengisahkan tentang perjuangan seorang difabel dalam mengukir prestasi. Film tersebut meraih nominasi dalam FLS2N, namun tidak berhasil meraih juara. Namun kemudian, film "Tanpa Batas" juga meraih tiga nominasi dalam ajang 
Minang Film Festival yang diselenggarakan oleh prodi televisi dan film ISI Padang Panjang. Dari tiga nominasi tersebut, film yang dibintangi oleh I memenangkan penghargaan yaitu Saluak Laka Awards.

Penelitian dilaksanakan pada tiga tempat yaitu sekolah dari tunarungu I yaitu SMAN 3 Padang Panjang, di rumah dari tunarungu I dengan alamat Jln. lintas Padang Panjang - Bukittinggi, Pincuran Tinggi, Nagari Panyalaian, Kabupaten Tanah Datar, Sumatera Barat. Serta di kantor Dinas Pariwisata Kota Padang Panjang yang beralamat Jl. Bustanil Arifin, SH. Silaing Bawah, Kec. Padang Panjang Barat, Kota Padang Panjang, Sumatera Barat.

Kemudian, perolehan data tersebut dideskripsikan berdasarkan tujuan penulisan tentang profil siswa tunarungu penyanndang gelar uni duta wisata kota Padang Panjang tahun 2018 yang terdiri atas:

\section{a. Riwayat pendidikan tunarungu I}

Berdasarkan hasil wawancara yang telah peneliti lakukan dengan tunarungu I, beberapa orang guru, teman sekelas dan keluarga , I menempuh pendidikan SD di SLB YPAC SUMBAR dari kelas 1 sampai dengan kelas 3, lalu pindah ke SD Merapi Padang Panjang di Kelas 4 sampai dengan tamat. I pindah sekolah dikarenakan bencana gempa bumi yang melanda Sumatera Barat tahun 2009. I melanjutkan SMP ke SMPN 5 Padang Panjang, dan saat ini I merupakan pelajar di kelas XII IPS 3 pada SMAN 3 Padang Panjang. I juga pernah mengalami perundungan ketika ia bersekolah di SMP dan juga SMA yang dilakukan oleh teman teman di sekolahnya hingga mengakibatkan trauma dan I juga sempat berniat untuk berhenti bersekolah. Di luar dari pendidikan formal tersebut, I tidak pernah mengikuti jalur pendidikan non-formal apapun.

b. Aspek Brain yang ada dalam diri tunarungu I sebagai seorang Uni Duta Wisata Kota Padang Panjang Tahun 2018

Aspek Brain berkaitan erat dengan intelektualitas. Berdasarkan pengamatan, wawancara dan study dokumentasi yang telah penulis laksanakan, penulis dapat menyimpulkan bahwa intelektualitas yang dimiliki oleh tunarungu I dapat dikatakan standar. Hal ini dibuktikan dengan prestasi di sekolahnya yang tidak dapat dikatakan buruk. Namun, menurut pendapat dari responden dalam catatan wawancara ke 7 yang dilaksanakan pada hari selasa tanggal 10 desember 2019, I memiliki pengetahuan yang luas mengenai tradisi juga sejarah dari kota Padang Panjang.

c. Aspek Beauty yang ada dalam diri tunarungu I sebagai seorang Uni Duta Wisata Kota Padang Panjang Tahun 2018

Dalam aspek Beauty, berhubungan dengan penampilan. Berdasarkan pengamatan yang telah penulis lakukan, penulis dapat menggambarkan penampilan tunarungu I sebagai berikut : Dari segi wajah, I memiliki wajah yang berbentuk bulat dengan mata yang sipit dan hidung yang bangir. Tunarungu I 
memiliki ekspresi wajah yang ceria dan penuh semangat.

Tunarungu I memiliki tinggi badan $157 \mathrm{~cm}$. Dan dapat dikatakan berat badan dan tinggi badannya seimbang. Postur badan I tegap, dan dalam berbusana penulis dapat menggambarkan bahwa gaya busana I sama sekali tidak berlebihan dan dalam kesehariannya, tunarungu I menggunakan hijab. I pandai dalam menempatkan diri, gaya busana dan keadaan yang sedang berlangsung. Tunarungu I memiliki penampilan sederhana namun sopan.

Tunarungu I sama sekali tidak berlebihan dalam berpenampilan. Namun dibalik kesederhanaan tersebut, ia tetap terlihat menarik.

d. Aspek Behavior dalam diri tunarungu I sebagai seorang Uni Duta Wisata Kota Padang Panjang Tahun 2018

Berdasarkan pengamatan dan hasil wawancara terkait I, penulis dapat menggambarkan bahwa I merupakan remaja yang sopan, tidak banyak tingkah dan bersemangat. Menurut anggota keluarga I, dalam catatan wawancara ke 5, I merupakan remaja yang memiliki rasa percaya diri yang tinggi dan kemauan yang keras. Dapat dikatakan bahwa I jauh dari kata pemalu seperti kebanyakan penyandang tunarungu. Adapun menurut pendapat responden yang tertuang dalam catatan wawancara ke-6, I mudah berbaur dengan lingkungannya dan ia juga senang bersosialisasi dengan orang baru

e. Rangkaian kegiatan yang dijalani tunarungu I pada ajang Uda Uni Duta Wisata Kota Padang Panjang Tahun 2018

Adapun rangkaian kegiatan yang di jalani oleh tunarungu I pada ajang Uda Uni Duta Wisata Kota Padang Panjang Tahun 2018 yaitu hanya berupa seleksi wawancara dan grandfinal. Berdasarkan pernyataan dari rekan duta wisata dan keluarga I, I tidak mengikuti proses karantina karena pihak penyelenggara membebaskan I untuk memilih akan mengikuti atau tidaknya.

Jadi, I hanya menghadiri tahap seleksi awal dan malam puncak grandfinal, Namun I juga berpartisipasi dalam pembuatan berbagai video promosi wisata yang dimiliki Kota Padang Panjang dan turut menyebarkannya di sosial media yang ia miliki

f. Kendala yang dialami tunarungu I dalam rangkaian kegiatan sebagai Uni Duta Wisata Kota Padang Panjang Tahun 2018

Menurut pernyataan I, ia tidak menemui banyak kendala selama berkompetisi. Adapun kendala terbesar yang ia hadapi hanya pada komunikasi dan ini merupakan dampak dari kebutuhan khusus yang dialaminya. Ini juga diperkuat oleh pernyataan rekan duta wisatanya, bahwa I tidak menjumpai banyak kesulitan dalam berkompetisi kecuali kesulitan berkomunikasi antar sesama dan kepada pihak penyelenggara. Karena pada dasarnya I sama sekali tidak merasa minder ataupun dibedakan dalam berkompetisi. Dengan keadaannya, I justru sangat bersemangat dan bertekad yang kuat 


\section{g. Solusi yang digunakan tunarungu I dalam mengatasi kendala yang ia alami sebagai seorang Uni Duta Wisata Kota Padang Panjang Tahun 2018}

Dikarenakan I tidak menemukan kendala apapun selain berkomunikasi, I berkomunikasi menggunakan bahasa isyarat namun tidak semua orang yang memahaminya, maka I menyiasati dengan media tulisan. Dan apabila ada dari panitia dan rekan duta wisata I yang ingin berkomunikasi dengan I namun tidak bisa menggunakan bahasa isyarat, maka mereka akan meminta bantuan kepada salah satu rekan duta wisata I yang dapat berbahasa isyarat. Hal ini terlihat dari wawancara tertulis yang di lakukan I serta melalui rekan duta wisatanya yang dapat menggunakan bahasa isyarat.

\section{Pembahasan}

Berdasarkan data yang diperoleh dalam penelitian, maka terjawablah semua tujuan penelitian dan keterkaitannya dengan teori-teori yang relevan. Berikut pembahasannya :

1. Tunarungu I menempuh pendidikan formal dari kelas 1 sampai dengan kelas $3 \mathrm{SD}$ di SLB YPAC SUMBAR. Lalu tunarungu I pindah ke SD merapi di Kota Padang Panjang pada kelas 4, dan menamatkan jenjang SD disana. Tunarungu I pindah sekolah dikarenakan rasa traumanya setelah kejadian gempa bumi besar yang melanda Sumatera Barat dan sekitarnya. Lalu tunarungu I melanjutkan SMP di SMPN 5 Kota Padang Panjang dan menamatkan pendidikannya disana. Setelah lulus dari SMPN 5 Kota Padang Panjang, tunarungu I melanjutkan pendidikannya di SMAN 3 Padang Panjang. Berdasarkan keterangan yang peneliti peroleh dari orangtuanya, I pernah menjadi korban perundungan (bullying) di SMP dan mengakibatkan ia tidak mau bersosialisasi karena rasa traumanya. Ia bahkan sempat berfikir untuk berhenti bersekolah di Padang Panjang dan pindah sekolah ke kota Payakumbuh untuk menghindari kejadian tersebut terulang lagi. Bahkan sampai di SMA pun, peneliti menemukan bahwa masih ada diantara teman-teman bahkan adik kelas I yang melakukan perundungan terhadap I, namun saat ini I sudah terbiasa sehingga ia tak lagi memikirkan masalah tersebut dan lebih fokus dalam menyelesaikan pendidikannya. Tunarungu I juga memiliki minat yang begitu besar dalam dunia seni peran, ini dibuktikan dengan peraihan Saluak Laka Awards pada Minang Film Fest yang di selenggarakan oleh prodi televisi dan film ISI Padang Panjang untuk film bertajuk “Tanpa Batas” yang ia bintangi. Peneliti juga menemukan bahwa tunarungu I berbakat dalam bidang seni lukis yang terlihat dari kemampuan tunarungu I dalam mengerjakan banyak gambar peta geografis dalam waktu yang bisa dibilang singkat. Hal ini juga didukung dengan pernyataan dari teman dekat I bahwasanya I memang sangat gemar menggambar dan bahkan ia pernah meraih juara dalam lomba menggambar pada masa taman kanak-kanak. Tunarungu I juga mengatakan bahwa ia ingin melanjutkan ke perguruan tinggi dengan jurusan sastra indonesia. Tunarungu I juga memiliki 
bakat dalam bidang seni tari dan dibuktikan di awal perjumpaan peneliti dengan tunarungu I di SLB YPAC SUMBAR saat peneliti sedang melaksanakan PLK, hal ini juga didukung dengan pernyataan dari orangtua dan rekan-rekan I bahwa ia juga sering diikut sertakan dalam kegiatan seni tari. Dengan segala kemampuan yang I miliki, peneliti menemukan fakta bahwa I sama sekali tidak pernah mengikuti kursus apapun. Dan kemampuan tersebut merupakan bakat dan minat alami yang I miliki tanpa intervensi dari pihak manapun.

2. Tunarungu I merupakan seorang remaja yang dapat dikatakan tidak memiliki prestasi akademik yang menonjol, namun ia memiliki pengetahuan yang cukup luas mengenai tradisi dan sejarah dari Minang Kabau dan kota Padang Panjang pada khususnya. Adapun keterbatasan I dalam memahami informasi terkait dengan hambatannya dan hal ini berhubungan dengan pendapat(Winarsih, 2007) yang menyatakan bahwa Tunarungu bisa diartikan sebagai sebuah keadaan hilangnya fungsi pendengaran yang mengakibatkan seseorang kurang atau bahkan tidak dapat menangkap dan merespon terhadap rangsangan suara dari sekitarnya. Apabila dikaitkan dengan aspek intelektualitas (brain) dapat penulis katakan bahwa tunarungu I memiliki intelektualitas yang cukup untuk mendukung predikatnya sebagai seorang dutawisata.

3. Dan apabila dikaji dari segi penampilan yang berkaitan dengan aspek beauty, penulis dapat menggambarkan bahwasanya I merupakan seorang remaja yang berpenampilan sederhana namun sopan. Dalam kesehariannya juga I sama sekali tidak menampilkan diri secara berlebihan. Dari kepribadian tunarungu I dapat kita lihat bahwa a merupakan seorang remaja yang memiliki tekad kuat, gigih dan penuh semangat. Tunarungu I juga mampu membawakan diri dengan baik kepada lingkungan dan ramah. Hal ini relevan dengan pendapat dari (PUTRA, 2017) yang mengatakan bahwa kriteria dari seorang duta wisata yaitu kemampuan seorang duta wisata untuk menampilkan dirinya dengan baik dihadapan khalayak dengan penampilan yang rapih, kebersihan diri yang terjaga dan yang paling penting berupa senyuman sebagai salah satu bahasa komunikasi universal yang dapat memberikan kesan baik kepada orang.

4. Berdasarkan aspek perilaku, diperkuat oleh pendapat dari beberapa orang responden, penulis dapat menggambarkan bahwa tunarungu I memiliki perilaku yang baik. Ia sama sekali tidak pernah memiliki catatan tingkah laku yang buruk di mata sekolah, rekan dan keluarganya. Kepribadiannya penuh semangat, gigih, ramah, supel dan periang. Tidak seperti kebanyakan tunarungu pada umumnya, I justru bersikap terbuka kepada siapapun yang hendak berinteraksi dengannya. Namun kebanyakan orang berpikir bahwa akan sulit untuk memulai komunikasi dengan I karenan keterbatasannya dan ketidak mampuan banyak orang dalam menggunakan bahasa isyarat. Hal ini tentu saja berkaitan dengan teori yang menyatakan bahwa seoran duta wisata dituntut untuk memiliki perilaku yang baik 
dikarenakan ia merupakan cerminan dari kondisi masyarakat tempatnya berasal (PUTRA,2017)

5. Berdasarkan pernyataan dari rekan duta wisata tunarungu I, idealnya tahapan yang harus dilalui oleh setiap finalis pemilihan Uda Uni Duta Wisata itu berupa tahapan seleksi awal, lalu tahapan karantina, dan selanjutnya penobatan pada malam grandfinal. Namun atas kebijakan dari pihak penyelenggara, I dibebaskan memilih untuk mengikuti semua tahapannya secara utuh maupun tidak. Berdasarkan informasi yang peneliti peroleh dari rekan duta wisata dan keluarga tunarungu I, ia memilih untuk tidak mengikuti rangkaian kegiatan tersbut secara utuh. I hanya mengikuti seleksi awal dengan wawancara tertulis, lalu I juga menghadiri beberapa latihan untuk persiapan pada malam grandfinal dan I juga menghadiri penobatan pada malam grandfinal. Selama menjalankan tugas sebagai duta wisata, masa dinas dari seorang duta wisata adalah 1 tahun terhitung dari tanggal ia dinobatkan sampai dengan malam penobatan di tahun setelahnya. Namun, hingga hari ini I masih terlibat aktif dalam menjalankan tugas sebagai duta wisata walaupun masa jabatannya sudah berakhir dan duta wisata baru telah dinobatkan. Hal ini dibuktikan dengan keikutsertaannya dalam ajang Tour de Singkarak pada tahun ini.

6. Dapat dikatakan selama mengikuti kompetisi Uda Uni duta wisata, tunarungu I tidak menemui kendala berarti. Tunarungu I mengalami kebanyakan kendala disebabkan oleh kebutuhan khususnya. Selama dalam masa kompetisi tersebut, I mengatakan bahwa semua teman-teman duta wisatanya bersikap sangat terbuka kepadanya, juga tidakmemandang I dengan sebelah mata. Ini terbukti dari pernyataan I bahwa semua teman-teman duta wisatanya selalu bersedia membantunya selama berkompetisi. Dan dari pernyataan yang peneliti dapatkan dari rekan duta wisatanya, mereka juga sangat senang dengan kehadiran I dalam ajang tersbut. Mereka melibatkan I dalam pembuatan video promosi pariwisata kota Padang Panjang dan meminta I untuk menerjemahkan pesan yang disampaikan kedalam bahasa isyarat. Rekan duta wisata I juga mengatakan bahwa justru dengan hadirnya I, kegiatan promosi pariwisata yang merupakan tugas mereka menjadi lebih menarik dan berbeda dari kabupaten, kota, bahkan provinsi karena hanya duta wisata kota Padang Panjang yang memiliki seorang duta wisata penyandang tunarungu

7. Solusi dari kendala yang ia alami yaitu dengan berkomunikasi menggunakan tulisan. Hal ini terlihat pada saat I menjalani sesi wawancara tertulis dan berdasarkan observasi yang peneliti lakukan, I juga mampu membaca bahasa oral dengan baik walaupun ia tidak mampu mengucapkannya kembali dan I merespon bahasa oral yang ditampilkan oleh lawan bicaranya dengan menggunakan bahasa isyarat sederhana dengan mengeja huruf dalam kata tersebut dengan bahasa isyarat dan apabila hal tersebut masih menemui kesulitan, maka I akan menuliskannya lewat HP ataupun kertas. Beruntungnya, sudah banyak dari 
lingkungan I yang mampu menggunakan bahasa isyarat sederhana seperti temanteman sekelasnya dan juga anggota keluarganya.

\section{Daftar Rujukan}

Achnes, S., \& Randa, R. (2015). Peran Duta Wisata dalam Mempromosikan Pariwisata Kabupaten Solok. Jurnal Online Mahasiswa Fakultas Ilmu Sosial Dan Ilmu Politik Universitas Riau, 2(2).

Andryan, K., Effendi, S., Santoso, E., \& Hidayat, N. (2018). Implementasi Metode TOPSIS Untuk Penentuan Finalis Duta Wisata Joko Roro Kabupaten Malang (Studi Kasus: Paguyuban Joko Roro). Pengembangan Teknologi Informasi Dan Ilmu Komputer, 2(2).

Bambang Putranto. (2015). Tips Menangani Siswa yang membutuhkan perhatian Khusus ( ragam Sifat dan Karakter Siswa "spesial" dan Cara Menanganinya) (Kurniawani, ed.). Yogyakarta: DIVA Press.

Darmadi, H. (2017). Pengembangan model dan metode pembelajaran dalam dinamika belajar siswa. Yogyakarta: Deepublish.

Devira, D., Hasanuddin, W. S., \& Zulfadhli, Z. (2017). PROFIL TOKOH PEREMPUAN DALAM NOVEL METROPOP SUNSHINE BECOMES YOU DAN IN A BLUE MOON KARYA ILANA TAN. Bahasa Dan Sastra, 5(1), 36-49.

Hartanti, Y. S. (2015). Penerapan Metode Multisensori Untuk Meningkatkan Kemampuan Pengucapan Kosakata Bahasa Indonesia Pada Anak Tunarungu. Universitas Pendidikan Indonesia.

Indonesia, R. (2003). Undang-undang Republik Indonesia nomor 20 tahun 2003 tentang sistem pendidikan nasional. Jakarta: Pemerintah Republik Indonesia.

Khairani, R., \& Sopandi, A. A. (2018). Meningkatkan Keterampilan Membuat Dendeng Daun Singkong Melalui Strategi Mastery Learning Bagi Anak Tunarungu. 6, 86-93.

Kurniawan, A. (2009). Prestasi Remaja di Daerah Abrasi. Indigenous: Jurnal Ilmiah Psikologi, 11(2).

Kusmarni, Y. (2012). Studi Kasus. UGM Jurnal Edu UGM Press.

Moleong, J. (n.d.). Lexy, Prof. Dr. 2012. Metode Penelitian Kualitatif.

Salim, M., \& Soemarsono, S. (1984). Pendidikan Anak Tunarungu. Jakarta: Depdikbud.

Sugiyono. (2015). Metode Penelitian Kuantitatif, Kualitatif dan REDD. Bandung: Alfabeta.

Susiani, D. (2009). Metode Penelitian dan Aplikasinya. Bumi Aksara: Jakarta.

Winarsih, M. (2007). Intervensi dini bagi anak tunarungu dalam pemerolehan bahasa. Jakarta. DepartemenPendidikandanKebudayaan.

Wulandari, P. K., Saraswati, D., \& Putra, S. D. E. (2017). Membangun Indonesia: pemberdayaan pemuda berwawasan Pancasila. Universitas Brawijaya Press.

(Achnes \& Randa, 2015; Andryan, Effendi, Santoso, \& Hidayat, 2018; Bambang Putranto, 2015; Darmadi, 2017; Devira, Hasanuddin, \& Zulfadhli, 2017; Hartanti, 2015; Indonesia, 2003; Khairani \& Sopandi, 2018; Kurniawan, 2009; Kusmarni, 2012; Moleong, n.d.; Salim \& Soemarsono, 1984; Sugiyono, 2015; Susiani, 2009; Winarsih, 2007; Wulandari, Saraswati, \& Putra, 2017) 